\title{
Trump's 2016 Presidential Campaign and Adorno's Psychological Technique: Content Analyses of Authoritarian Populism
}

\author{
Myra B. Haverda* and Jeffrey A. Halley** \\ *(Corresponding author) University of Oregon, Eugene, USA, \\ thaverda@uoregon.edu, https://orcid.org/0000-0001-6222-2766, \\ https: //myrahaverda.wordpress.com/ \\ ** The University of Texas at San Antonio, San Antonio, USA, \\ jeffrey.halley@utsa.edu, http://colfa.utsa.edu/sociology/faculty/halley
}

\begin{abstract}
There has been a burgeoning interest in the sociology of the Frankfurt School as well as the oeuvre of Theodor W. Adorno since the 2016 presidential campaign of Donald J. Trump. The objectives of this study are to both illustrate the enduring importance of Adorno and to provide an important theoretical outline in making sense of Trump's 2016 United States presidential campaign. Using Adorno's understudied textual analysis of the radio addresses of Martin Luther Thomas and data from Trump's 2016 US presidential campaign, we find that Trump's own discourse can be condensed into three of Adorno's rhetorical devices: (1) the lone wolf device or anti-statism/pseudo-conservatism, reflecting his criticism of "special interests" and his appraisal of business and (self-)finance; (2) the movement device, which amounted to glorification of action; and (3) the exactitude of error device which amounted to xenophobic, ethnonationalist hyperbole.
\end{abstract}

Keywords: Donald Trump, Theodor W. Adorno, authoritarian populism, critical theory, 2016 US Presidential Election, content analysis

\section{Introduction}

Near the conclusion of Donald Trump's 2017 inaugural address, the recently-elected President of the United States declared, "We will no longer accept politicians who are all talk and no action - constantly complaining but never doing anything about it. The time for empty talk is over. Now arrives the hour of action" (Trump 2017). This electoral victory of a right-wing demagogue and authoritarian populist continues to be one of the most puzzling social phenomena in recent memory. Still, one explanation for this phenomenon can be explicated through the elements of 'authoritarian populism' that was a recurring feature throughout his presidential campaign: anti-statism, calls for "action", and xenophobic, ethnonationalist hyperbole.

The present study seeks to provide a theoretical framework for understanding and analysing Trump. With his presidential election and the recent resurgence of authoritarian populism both in the United States and internationally, there has been a renewed interest in the research of the Frankfurt Institute of Social Research - known as critical theory or the Frankfurt School (e.g. Ballestín 2017; Bernstein 2017). In this article, we discuss Theodor W. Adorno's The Psychological Technique of Martin Luther Thomas' Radio Addresses (2000), an underutilised yet immensely useful study of the radio addresses of Martin Luther Thomas, a far-right, anti-Semitic, and Christian 'demagogue' in California during the 1950s. As such, the objectives of this study are 
twofold: first, to draw attention to and provide a demonstration of the contemporary relevancy of Adorno; and second, to provide a content analysis using Adorno's devices by analysing Donald Trump's 2016 campaign.

This study begins with a brief introduction to Theodor W. Adorno, elaborating on his continued significance on understanding contemporary right-wing demagoguery and authoritarian populism. This study situates Trump as an authoritarian populist who embodies three noteworthy ideologies of authoritarian populism: (1) anti-statism or pseudo-conservatism, (2) glorification of action, and (3) xenophobic, ethnonationalist hyperbole. Using three rhetorical devices from Adorno's textual analysis of authoritarian populism - (1) lone wolf, (2) movement, and (3) exactitude of error - this study conducts a textual analysis of Trump, drawing from sixteen texts from his 2016 presidential campaign: Trump's presidential announcement speech, the Republican Party presidential primary debates, the United States presidential election debates, and Trump's inaugural address.

\section{Adorno, Trump, and Authoritarian Populism}

Theodor W. Adorno (1903 - 1969) was a German scholar interested in interdisciplinary issues of sociology, psychoanalysis, philosophy, and art who - along with other members of the Frankfurt Institute for Social Research like Max Horkheimer, Herbert Marcuse, and Erich Fromm (or, alternatively, 'the Frankfurt School') - was most known for his cultural critiques of capitalism, fascism, and anti-Semitism. Social research for the Frankfurt School underscored "a materialist theory enriched and supplemented by empirical work" that was interdisciplinary and inclusive of social psychology (Jay 1973, 25,27 ). Their journal, the Zeitschrift für Sozialforschung (Journal for Social Research), continued for nearly a decade (from 1932 to 1941) and further reflected their wide scholarly interests. As members of the Institute for Social Research, these theorists emphasised the importance of ideology in maintaining the economic foundation of capitalism. In particular, the Frankfurt School expounded on social-psychological explanations for the rise of fascism and anti-Semitism both in Nazi Germany and in the United States, which could be explicated through a critical theory of society. After fleeing Nazi Germany with other members of the Institute, Adorno conducted research with the goal of producing new empirical and theoretical knowledge elucidating the contemporary social processes contributing to rise of authoritarian populism. Two particularly informative works in understanding authoritarian populism were undertaken by Adorno - the widely cited The Authoritarian Personality (Adorno et al. 1950) and Dialectic of Enlightenment (Horkheimer and Adorno 1972).

Today, Adorno remains more relevant than ever. Instances demonstrating the contemporary relevance of Adorno and the Frankfurt School are plentiful, including the intersections between Adorno and analyses of the Christian right (Apostolidis 2000; Brittain 2018) and an overall renewed interest in the authoritarian personality to explain the rise of US president Donald J. Trump (Gordon 2016; Ross 2016). Similarly, Adorno's insight into authoritarian populism has proved useful in understanding Trump (see Ballestín 2017; Bernstein 2017). Furthermore, recent work utilising Psychological Technique (Adorno 2000) has primarily focused on its capacity to explain the religious phenomena of the Christian right (Apostolidis 2000; Brittain 2018). However, Trump's discourse is remarkably secular, and, unlike other leaders of the New Right (e.g. Ronald Reagan, William F. Buckley Jr.), Trump's discourse also devotes a substantial amount of time dedicated to self-characterisation ("I know politicians better than you do", "I'm self-funding my campaign", etc.). Thus, Psychological Technique remains a worthy avenue of understanding not solely the religious aspects of authoritarian 
populism but also its secular, non-religious aspects. This work by Adorno (2000) addresses criticisms of his work as being purely theoretical or unempirical ${ }^{1}$ by providing a deep textual analysis of authoritarian populism. Moreover, Psychological Technique is a sole-authored work, which highlights Adorno's ability to be a theoretically meticulous and 'empirical' sociologist. However, Psychological Technique has largely escaped scholarly reception due to the recency of its publication.

It is clear that Donald Trump embodies many of the characteristics of populism, notably through his anti-elitist rhetoric, and thus has been characterised in numerous accounts as an authoritarian populist (e.g. Abromeit 2018, 18; Kellner 2018a; Müller 2016) and/or as a demagogue (e.g. Fuchs 2018; Johnson 2017). While the term 'populism' has been plagued by conceptual ambivalences, there are clearly two central tenets that make up the core ideology of populist politics: an appeal to 'the people' (as vague or ambiguous as the implications of this term may be) and denunciation of the social and political elite (Kellner 2018b; Morelock and Narita 2018, 137; Müller 2016, passim, esp. 100-101; Pelinka 2013; Rydgren 2003). What differentiates US right-wing populism from left-wing populism is the former's emphasis on American exceptionalism, ethnonationalism, and xenophobia (Pelinka 2013; Rydgren 2003). Similarly, Gandesha $(2018,62)$ writes: "right-wing or authoritarian populism defines the enemy in personalized terms; while this is not always true, left-wing populism tends to define the enemy in terms of bearers of socio-economic structures and rarely as particular groups". This characterisation, in part, helps to explain the appeal of a rightwing or authoritarian populist like Trump, as well as his uniqueness relative to other candidates within the political field and across the political spectrum.

Furthermore, this characterisation of Trump as demagogue more clearly positions him as a captivating leader who wishes his audience to identify themselves on the basis of imagined precariousness and perceived victimisation (see Johnson 2017; Maly, Dalmage and Michaels 2012). These anxieties have real causes, and they are not only 'imaginary'. Nevertheless, Trump's demagoguery reflects a shift away from concrete political programs and toward mobilising political anxieties. Put succinctly, Trump's discourse during the 2016 presidential campaign includes a variety of rhetorical flourishes that stir up these arguments of precarity, while also seeking to establish some form of idealistic political and economic stability for his constituents. Trump's campaign slogan that was first announced in his presidential announcement speech, "Make America Great Again" (Time 2015), is the clearest example of this symbolic precarity, as it wishes to reinstate a form of power through a narrative of nostalgia.

It is worth noting three important ideologies within authoritarian populism. The first tendency in authoritarian populism worth noting is what could be broadly conceptualised as 'anti-statism' and what is known within Adorno's contribution within The Authoritarian Personality as "pseudo-conservatism" and "the usurpation complex" (Adorno et al. 1950, 675-689; see Abromeit 2018, 8-10). This tendency is a sceptical

1 This characterisation of Adorno as purely theoretical or unempirical is largely a popular conceptualisation with no basis in reality. Gerard Delanty (2012) remarked that "Adorno was a product of Germany's unempirical sociological tradition". Delanty (2012) offers more general criticisms by remarking, "It is difficult to conclude that Adorno misunderstood not much of social life, but also had a poor understanding of social science". Klaus von Beyme $(2014,80)$ similarly remarked that Adorno's "studies on radio diffusion and fascism [as well as music, amounted to an] unempirical approach". For a detailed presentation of the research programme of the Institute for Social Research, see Dubiel (1985, 119-182). For Adorno's account of the relation of theory and research, see Adorno et al. (1976, 68-86). 
yet largely superficial critique of more hegemonic political ideologies. Among US authoritarian populism, criticism against 'bureaucrats' and 'politicians' operates as an effective scapegoat of what is perceived (perhaps rightly) as a relatively impersonal institution that governs social life along with a particular distortion of capitalist exploitation that functions as a more covert anti-Semitism. In The Authoritarian Personality, for example, Adorno remarked that,

[...] "the bureaucrat" [...] has become a magic word, that he functions as a scapegoat to be blamed indiscriminately for all kinds of unsatisfactory conditions, somewhat reminiscent of the anti-Semitic imagery of the Jew with which that of the bureaucrat is often enough merged. [...] The bureaucrat is the personalization of ununderstandable politics, of a depersonalized world (Adorno et al. 1950, 693-695).

For Adorno, criticism of "bureaucrats, politicians, merchants, and especially bankers" within the United States operated as "bourgeois anti-Semitism" that sought to unite wage labour and capital (Abromeit 2018, 10-11). The centralistic nature of US government and the "bogy of "bureaucracy" could be "directed against the interest of the people" (Adorno 2000, 113-114). Fascist agitators, Adorno notes, may therefore distort the problems caused by capitalistic production into "devilish schemes" and conspiracies against the interests of the class-reductionary and conceptually ambivalent term "the people" $(2000,109)$.

The second ideology in authoritarian populism worth identifying is the glorification of action. Umberto Eco writes that fascism depends on the logic of "action for action's sake" (1995) which reflects a broader admiration toward aggression, antiintellectualism, and irrationalism. Support for domineering leaders - in this case embodied through action - is a common theme among Trump voters (Smith and Hanley 2018). This support for authoritarianism confirms the notion that Trump embodies a certain dominance over others, especially through violent rhetoric (e.g. "if you see somebody getting ready to throw a tomato, knock the crap out of them, would you? [...] I promise you I will pay the legal fees", "any guy that can do a body slam, he is my type!" etc.).

The third and final ideology in authoritarian populism worth noting is the employment of varied xenophobic or ethnonationalist rhetoric and racist dog whistles. This racial discourse common to authoritarian populism includes the popular punitive slogan of "law and order", providing a rather racially colour-blind discourse with a racist subtext that works as a form of social control (see Hall et al. 2013). As Michelle Alexander in The New Jim Crow (2011) writes,

A new race-neutral language was developed for appealing to old racist sentiments, a language accompanied by a political movement that succeeded in putting the vast majority of blacks back in their place. Proponents of racial hierarchy found they could install a new racial caste system without violating the law or the new limits of acceptable political discourse, by demanding "law and order" rather than "segregation forever" (Alexander 2011, 40).

Through emphasising "law and order", US authoritarian populists could strategically and covertly promote a white supremacist and therefore racist agenda. In the 1950s and 60s, for example, emphasising "law and order" worked to support segregation and attempted to halt Civil Rights legislation (Alexander 2011, 40). After the passage of the Civil Rights Act of 1964, however, "law and order" continued to signify the defence of 
white supremacism through Nixon's Southern Strategy. It was by emphasising "law and order" and various racially coded issues that US conservatism rose in popularity in the 1960s, and "law and order" became a major issue for the US Republican Party (Alexander 2011, 40-58; Flamm 2007). This white supremacist tendency continues today as a way of playing on social anxieties around crime rates, which must be grossly over-exaggerated if the criminal justice system is to remain intact, despite crime rates declining in the aggregate. ${ }^{2}$ In addition, this "law and order" discourse must maintain the façade of racial colour-blindness where explicit white supremacism and overt racism is becoming increasingly repudiated not altogether abandoned among the popular electorate.

To summarise, there are three important ideologies of US authoritarian populism: (1) anti-statism, (2) glorification of action, and (3) xenophobic hyperbole. We hope to show that Trump is indeed an authoritarian populist who utilised these ideologies in his 2016 presidential campaign. By drawing on Adorno's study of authoritarian populism in the 1950s, we hope to show that these same devices were used by Donald Trump in the 2016 US presidential election. This study is therefore intended to provide both an empirical case study of authoritarian populism and renew interest in an understudied (yet both theoretically and empirically useful) part of Adorno's wider bibliography: The Psychological Technique of Martin Luther Thomas's Radio Addresses. It is to this work by Adorno that we now turn.

\section{Psychological Technique: Adorno's Content Analysis of Authoritarian Populism}

It is worth stressing that the context of Adorno's Psychological Technique (2000) is a study of a Christian and today relatively unknown demagogue - Martin Luther Thomas. Through frequent radio addresses that often contained xenophobic and anti-Semitic content, Thomas would disseminate his message to a wide listening audience in the California area. Adorno was one such listener and catalogued a variety of messages by Thomas from May to July 1935. Adorno noted that these concepts were universally valid for all right-wing demagogues; as Adorno writes, his thirty-three devices could be "employed by practically all fascist agitators [as] different speakers use the same clichés" (Adorno 1994, 168).

There are several advantages to using Psychological Technique as the primary analytical frame. Principally, it is one of the most insightful (yet clearly underutilised) works in Adorno's oeuvre, providing a more rigorous critique than his previous work that results in a "more radical and theoretically more sophisticated [work] than [The Authoritarian Personality and Prophets of Deceit]" (Apostolidis 2000, 62). Indeed, Adorno's devices themselves are part of a larger pattern in authoritarian populism, with scholars noting the usefulness in using Adorno's Psychological Technique to explain the religious aspects of authoritarian populism (Apostolidis 2000; Brittain 2018). As Trump is primarily devoted to self-characterisation and, unlike other prominent figures in the New Right, seldom uses religious terminology (at least in his 2016 US presidential campaign), we focus primarily on the secular, non-religious aspects of Adorno's characterisation of authoritarian populism.

Through Adorno's book, The Psychological Technique of Martin Luther Thomas' Radio Addresses (2000), we investigate various texts from Donald Trump's 2016 presidential campaign. From Adorno, we extract and examine the variety of "psychological techniques", propaganda "tricks", or what this study more accurately terms rhetorical devices, that Adorno uses to characterise Thomas and his discourse.

\footnotetext{
${ }^{2}$ For discussions of trends in crime rates, see Gramlich (2019) and James (2018).
} 
Among the 33 total devices Adorno catalogues, there are three of principal significance in this study: (1) the 'lone wolf' device, (2) the movement device, and (3) the exactitude of error device. As we show in the next section, these devices respectively correspond to aforementioned patterns of authoritarian populism: (1) anti-statism, (2) glorification of action, and (3) xenophobic, ethnonationalist hyperbole.

To construct an adequate representation of Donald Trump's discourse, we draw on a variety of audio, visual, and textual data featuring Trump during the 2016 US presidential election. Similar to previous studies that have used presidents' public presentations in their analysis - such as analysing presidential debates (Gordon and Miller 2004; Marietta 2009; Reber and Benoit 2001) and inaugural addresses (Frank 2011) - this study transcribed audio data from Trump's presidential announcement speech, the televised Republican Party presidential primary debates, the United States presidential election debates, and Trump's inaugural address, cumulating in a total of sixteen texts $(N=16)$. The date of these texts ranged from June 16, 2015 (the date of Trump's presidential announcement speech) to January 20, 2017 (the date of the inaugural address). Three presidential debates between Donald Trump and Democratic nominee Hillary Clinton occurred on September 26, October 9, and October 19. These presidential debates were also transcribed and coded for possible devices. A table with columns delineated by chronological number (\#), date in $\mathrm{DD} / \mathrm{MM} / \mathrm{YY}$ format (Date), the subject of the forum (Subject, e.g. 1st presidential debate, 5th Republican debate, etc.) and website of the transcript (URL) can be found in Table 1 below, and the texts are hereafter listed in the findings as (\#), where \# corresponds to chronological number.

\begin{tabular}{|c|c|c|c|}
\hline \# & Date & Subject & URL \\
\hline 01 & $16 / 06 / 15$ & $\begin{array}{l}\text { Presidential } \\
\text { Announcement } \\
\text { Speech }\end{array}$ & $\begin{array}{l}\text { http://time.com/3923128/donald-trump- } \\
\text { announcement-speech/ }\end{array}$ \\
\hline 02 & $06 / 08 / 15$ & $\begin{array}{l}1^{\text {st }} \text { Republican } \\
\text { debate }\end{array}$ & $\begin{array}{l}\text { https://www.washingtonpost.com/news/post- } \\
\text { politics/wp/2015/08/06/annotated-transcript-the-aug- } \\
\text { 6-gop-debate/ }\end{array}$ \\
\hline 03 & $16 / 09 / 15$ & $\begin{array}{l}2^{\text {nd }} \text { Republican } \\
\text { debate }\end{array}$ & $\begin{array}{l}\text { http://time.com/4037239/second-republican-debate- } \\
\text { transcript-cnn/ }\end{array}$ \\
\hline 04 & $28 / 10 / 15$ & $\begin{array}{l}3^{\text {rd }} \text { Republican } \\
\text { debate }\end{array}$ & $\begin{array}{l}\text { http://time.com/4091301/republican-debate- } \\
\text { transcript-cnbc-boulder/ }\end{array}$ \\
\hline 05 & $10 / 11 / 15$ & $\begin{array}{l}4^{\text {th }} \text { Republican } \\
\text { debate }\end{array}$ & $\begin{array}{l}\text { http://time.com/4107636/transcript-read-the-full-text- } \\
\text { of-the-fourth-republican-debate-in-milwaukee/ }\end{array}$ \\
\hline 06 & $15 / 12 / 15$ & $\begin{array}{l}5^{\text {th }} \text { Republican } \\
\text { debate }\end{array}$ & $\begin{array}{l}\text { https://www.washingtonpost.com/news/the- } \\
\text { fix/wp/2015/12/15/who-said-what-and-what-it-meant- } \\
\text { the-fifth-gop-debate-annotated/ }\end{array}$ \\
\hline 07 & $14 / 01 / 16$ & $\begin{array}{l}6^{\text {th }} \text { Republican } \\
\text { debate }\end{array}$ & $\begin{array}{l}\text { https://www.nytimes.com/2016/01/15/us/politics/tran } \\
\text { script-of-republican-presidential-debate.html }\end{array}$ \\
\hline 08 & $06 / 02 / 16$ & $\begin{array}{l}8^{\text {th }} \text { Republican } \\
\text { debate }\end{array}$ & $\begin{array}{l}\text { http://time.com/4210921/republican-debate- } \\
\text { transcript-new-hampshire-eighth/ }\end{array}$ \\
\hline 09 & $13 / 02 / 16$ & $\begin{array}{l}9^{\text {th }} \text { Republican } \\
\text { debate }\end{array}$ & $\begin{array}{l}\text { http://time.com/4224275/republican-debate- } \\
\text { transcript-south-carolina-ninth/ }\end{array}$ \\
\hline
\end{tabular}




\begin{tabular}{|c|c|c|c|}
\hline 10 & $25 / 02 / 16$ & $\begin{array}{l}10^{\text {th }} \text { Republican } \\
\text { debate }\end{array}$ & $\begin{array}{l}\text { https://www.washingtonpost.com/news/the- } \\
\text { fix/wp/2016/02/25/the-cnntelemundo-republican- } \\
\text { debate-transcript-annotated/ }\end{array}$ \\
\hline 11 & $03 / 03 / 16$ & $\begin{array}{l}11^{\text {th }} \text { Republican } \\
\text { debate }\end{array}$ & $\begin{array}{l}\text { http://time.com/4247496/republican-debate- } \\
\text { transcript-eleventh-detroit-fox-news/ }\end{array}$ \\
\hline 12 & $10 / 03 / 16$ & $\begin{array}{l}12^{\text {th }} \text { Republican } \\
\text { debate }\end{array}$ & $\begin{array}{l}\text { https://www.nytimes.com/2016/03/11/us/politics/tran } \\
\text { script-of-the-republican-presidential-debate-in- } \\
\text { florida.html }\end{array}$ \\
\hline 13 & $26 / 9 / 16$ & $\begin{array}{l}1^{\text {st }} \text { Presidential } \\
\text { debate }\end{array}$ & $\begin{array}{l}\text { https://www.politico.com/story/2016/09/full-transcript- } \\
\text { first-2016-presidential-debate-228761 }\end{array}$ \\
\hline 14 & $9 / 10 / 16$ & $\begin{array}{l}2^{\text {nd }} \text { Presidential } \\
\text { debate }\end{array}$ & $\begin{array}{l}\text { https://www.politico.com/story/2016/10/2016- } \\
\text { presidential-debate-transcript-229519 }\end{array}$ \\
\hline 15 & $19 / 1016$ & $\begin{array}{l}3^{\text {rd }} \text { Presidential } \\
\text { debate }\end{array}$ & $\begin{array}{l}\text { https://www.washingtonpost.com/news/the- } \\
\text { fix/wp/2016/10/19/the-final-trump-clinton-debate- } \\
\text { transcript-annotated/ }\end{array}$ \\
\hline 16 & $20 / 01 / 17$ & $\begin{array}{l}\text { Inaugural } \\
\text { Address }\end{array}$ & https://www.whitehouse.gov/inaugural-address \\
\hline
\end{tabular}

Table 1: List of debates, forums, and speeches $(N=16)$

Consistent with previous research on presidential debates and inaugural addresses, we conducted a qualitative content (or textual) analysis with multiple pass-throughs of the data. As such, the transcriptions were coded by hand for possible themes or patterns of meaning (see Fereday and Muir-Cochrane 2006; Saldaña 2016). Major themes were anchored to Adorno's devices with special attention paid to the three aforementioned tendencies of authoritarian populism (xenophobia, anti-statism, and glorification of action). Transcripts were condensed into a single document, and subsequently modified so that Trump was the sole speaker, thereby facilitating greater practicality and expediency during the coding process (a single document containing approximately 70,000 words spoken by Trump at the 16 debates, forums, and speeches is available on request). Data analysis was conducted through NVivo, a qualitative data analysis software that facilitates data management and coding during the process of data analysis (see Richards and Richards 2003; the project file for NVivo is available on request).

\section{The Lone Wolf Device: Anti-Statism}

The 'lone wolf' device mobilises political anxieties about the impersonal political structure and allows the audience to identify with the demagogue, channelling these political anxieties and subsequently directing their anger at vague interests and individuals. As Adorno $(2000,4)$ writes, "The lone wolf device is taken from the arsenal of Hitler, who always used to boast [...] about the fact that others controlled the press, the radio - everything; and that he had nothing". For authoritarian populism in the present-day United States, the demagogue amends the device by "playing upon the American distrust of the professional politician. [...] Since [he] himself, like his fellow agitators, shows all the characteristics of a political racketeer, fewer will believe him a racketeer, if he thus violently attacks racketeering" (Adorno 2000, 4). As such, the lone wolf device criticises existing US politics and also offers an element of selfcharacterisation, commonly positioning the speaker/demagogue as opposed to these "special interests". This type of self-characterisation under late capitalism may be 
understood as "the self as a brand. Social media as cultural commodities articulate and produce familiar discourses that resonate with other products of the culture industry [...] where language is simple yet pompous and flashy" (Gounari 2018). Rather than asociality or introversion that fits the more idiomatic definition of the term 'lone wolf' employed in reference to perpetrators of mass-scale physical violence (e.g. Timothy McVeigh, Theodore Kaczynski), the lone wolf device is a rhetorical technique where the demagogue may portray themselves as a solitary yet still ruthless leader - 'solitary' in the sense that the demagogue presents themselves as alone in the political field, yet ruthless in the sense that the demagogue self-characterises as the authoritative will of the people.

Trump's evocation of the US political system is a recurring theme throughout the 2016 presidential campaign. As a comprehensive system made up of highly skilled employees, US politics (including politicians, legislators, corporations and interest groups) remain largely unknown to the average voter (Pew Research Center 2010; Walker 2014). Although contempt for the current state of affairs in the US political system was employed by two of the leading candidates - Bernie Sanders and Jill Stein ${ }^{3}$ - this contempt was also repeatedly employed by Trump. In conjunction with demystifying the US political system, Trump also provides a denigration of politics and politicians despite obviously being a politician himself. Indeed, Trump's discourse is heavily involved with reifying the political structure of US society. This reification includes the repeated utterance of words like "special interest" or "lobbyists", which are moulded into a general object of disdain and rendered as the solitary problem of social and economic life.

Trump's usage of the lone wolf device is evident as early as his presidential announcement speech. In it, Trump talks of politicians being "controlled fully - they're controlled fully by the lobbyists, by the donors, and by the special interests, fully" (01). During the second Republican debate, Trump exclaimed that, "a lot of money was raised by a lot of different people that are standing up here. And the donors, the special interests, the lobbyists have very strong power over these people" (03). Under no circumstances does the solution for ridding the United States of these "special interests" appear on the horizon, though Trump promises that through electing him to presidential office, the typical voter will (finally) achieve power over this mystical political structure, thereby ushering in a period where the United States is "great again". In fact, the "special interests" themselves never materialise, as Trump often proclaims that he will not "mention their names" (14) or "point them out" (10).

In addition, Trump's continual reminders of his previous experience as a businessman involved with politicians is evoked as a 'necessary evil' to his determined social role, forming a recurring referent that Trump points to as an entirely problematic structure that ties the political sector with the business sector. This rhetoric therefore plays on the real problem of US politics, but offers no solution. Furthermore, it trickily and almost hypocritically frames this political structure as an individual choice by

${ }^{3}$ For instance, Green Party candidate Jill Stein (in Galloway 2016) remarked that, "They [Trump and Clinton] are both representatives of oligarchy". In addition, Democratic Party candidate Bernie Sanders (2010) penned an article in The Nation titled, "No to Oligarchy". While examination of the term "oligarchy" is outside of the scope of this article, it should be mentioned that this term has a decisively different conceptualisation to Trump's usage of the terms "special interests" and "lobbyists" which evokes an individualised conspiracy typical of authoritarian populism rather than a structural/instrumental critique of capitalist democracy and social inequality. 
constructing an 'insider/outsider' status - as a 'successful' businessman, it allows for Trump to say that he can 'step outside' politics:

Trump emphasizes his status as an outsider, who is financing his own campaign rather than accepting any corrupting money from established special interest groups, and who is running for president only because he is 'fed up' with the 'crooked system' that is destroying American democracy and thwarting the expression of the will of the people. [...] Trump explains to his audience that he has decided reluctantly to enter politics, because the U.S. needs to get its house in order and that he is the perfect man for the job. He insists that his achievements as a wealthy businessman, successful real estate developer and tough negotiator are the ideal qualifications to 'make America great again.' [...] Trump plays on this type of populist, anti-political resentment, when he states repeatedly in his speeches that the current political system is corrupt, but that he as an individual possesses the wherewithal not only to reverse America's lamentable decline, but to do so quickly: 'You need somebody fast,' and 'it's gonna go fast,' and 'I alone can fix this problem' (Abromeit 2018, 15-16).

As illustrative of this insider/outsider status, Trump says, "I've actually been in politics all my life, although I've been on that side as opposed to this side. I'm now a politician for about three months. Obviously, I'm doing pretty well. I'm number one in every polls [sic] by a lot" (03). In the same debate, Trump proclaims,

I'm spending all of my money [...] I turn down so much, I could have right now from special interests and donors, I could have double and triple what he's [Jeb Bush's] got. I've turned it down. I turned down last week \$5 million from somebody. So, I will tell you I understand the game, I've been on the other side all of my life. And they have a lot of control over our politicians. [...] I am not accepting any money from anybody. Nobody has control of me other than the people of this country. (03)

Rather than resolving the combination of US politics with big business, this insider/outsider status works as a primary motivation to vote for Trump, serving as a testament to his indefatigability ("I turn down so much", "I understand the game", "I'm number one in every poll", etc.). Trump's self-characterisation is not too dissimilar from the 1950s authoritarian populist Martin Luther Thomas when the latter remarks: "[...] my work is a labour of love. I am asking you only to sacrifice with me. I don't ask you to work as hard as I work" (Adorno 2000, 13).

Trump often bragged about having self-financed his presidential campaign, reflecting a self-denial of capital from big bureaucracy (e.g. "I turn down so much [...] from special interests and donors"). Moreover, Trump's frequent boasting of his capital to fund his own presidential campaign represents a form of individual and continual perseverance over business and politics, insofar as he has tirelessly worked to achieve his own economic capital, and now endlessly toils to achieve political prosperity over "special interests" and "lobbyists" who are all conspiring against him. ${ }^{4}$ It is through this projection of indefatigability that Trump can represent himself as a lone wolf, alone in the field of "special interest and donors", while contradictorily also representing himself

${ }^{4}$ Despite this appearance of self-finance, Trump received nearly $\$ 47,000,000$ from large individual monetary contributions (contributions larger than $\$ 200$ ) and $\$ 65,000,000$ from SuperPACS (Center for Responsive Politics 2018). 
as a populist and self-funding his campaign in the interests of the people, despite being heavily funded by large campaign contributions and therefore these same "special interests" that he claims to oppose. When Trump concluded one debate with, "I'm working for you. l'm not working for anybody else" (09), his personal success (as well as his indefatigability) in accumulating economic capital was portrayed as instrumental to his political success.

For Trump, the lone wolf device revolves heavily around the language of finance and self-finance in conjunction with the usual criticisms of "lobbyists". Like Thomas' addresses, remarking "I have no sponsors, and no politicians ever put one dollar into this movement" (Adorno 2000, 4), Trump uses the same technique of the lone wolf device, remarking that he "does not need anybody's money. I'm using my own money. I'm not using the lobbyists. I'm not using donors. I don't care. I'm really rich" (01). Consider further examples during his presidential campaign:

I am the only person in either campaign that's self-funding. (04)

Over the years, l've created tens of thousands of jobs and a great company. It's a company l'm very proud of. Some of the most iconic assets anywhere in the world. And I will tell you, I don't have to give you a website because I'm selffunding my campaign. I'm putting up my own money. (05)

There is total control of the candidates, I know it better than anybody that probably ever lived. [...] And frankly, I know the system better than anybody else and I'm the only one up here that's going to be able to fix that system because that system is wrong. (12)

While these excerpts provide some examples of Trump's criticism toward US politics, the above excerpts are also illustrative of Trump's self-presentation as personally indefatigable. As it is clear in Trump's final quote above - "I know the system better than anybody else and I'm the only one up here that's going to be able to fix that system because that system is wrong" (12) - Trump's personal indefatigability is a highly political aspect, separating himself from other politicians who cannot or do not selffinance their campaign and do not have previous experience in business.

Trump's indefatigability synthesizes the personal with the political. One example of this personal-political synthesis are the themes of finance and self-finance, which subsequently stake out a position as a social actor within the broader political structure. Immediately succeeding Trump's above mention of politicians being "controlled fully by the lobbyists, by the donors, and by the special interests", is Trump's mentioning, "Hey, I have lobbyists. I have to tell you. I have lobbyists that can produce anything for me. They're great" (01). This previous access to lobbyists (which Trump has apparently now shut out) was evident in the tenth Republican debate, for example, as Trump remarked that, "some of the people in the audience are insurance people, and insurance lobbyists, and special interests. They got - I'm not going to point to these gentlemen, of course, they're part of the problem" (10).

\section{The Movement Device: Glorification of Action}

The "Movement" device (Adorno 2000, 31-32) has to do with the vagueness of the authoritarian populist's political objectives and "the glorification of action". As Adorno writes, for authoritarian populists, "The movement is conceived of as an end in itself, like the Nazis who always made a fetish of the term Bewegung ["move" or "the 
movement"] without pointing out exactly where the Bewegung was going" $(2000,31)$. The objectives of the authoritarian populist are centred on an appeal to the negative, lacking in any definite or decisive characterisations; rather than proposing any concrete attributes, the political program of the authoritarian populist is instead described by what it is not. Indeed, Trump's proposed healthcare plan was self-characterised as notObamacare:

Obamacare is going to be repealed and replaced. [...] I would absolutely get rid of Obamacare. We're going to have something much better [...]. Get rid of Obamacare, we'll come up with new plans. [...] We have to get rid of Obamacare. [...] All of the things that I've been talking about, whether it's trade [...] or knocking out Obamacare and coming up with something so much better, I will get it done. (10)

This appealing-to-the-negative approach in authoritarian populism has proved alluring in mobilising social anxieties precisely because it is directed at what are deemed as infamous individuals rather than putting into place tangible agendas. As Adorno writes, right-wing demagogues and authoritarian populists believe that their audience's "ambition should be centred around the pleasure which the movement itself may yield, not around the ideas which it might possibly materialize" (Adorno 2000, 32).

As the movement device glorifies action, Trump often uses this trick in a rather explicit manner, remarking that "politicians are all talk, no action", with little variation [emphasis added by present authors]:

Well, you need somebody, because politicians are all talk, no action. Nothing's gonna get done. (01)

We need people that know what the hell they're doing. And politicians, they're all talk, they're no action. And that's why people are supporting me. (09)

There is nobody on this stage that has done more for Israel than I have. Nobody. You might say, you might talk, you're politicians, all talk, no action. (10)

Nobody knows politicians better than I do. They're all talk, they're no action, nothing gets done. (10)

I don't believe these politicians. All talk, no action. (11)

We will no longer accept politicians who are all talk and no action - constantly complaining but never doing anything about it. The time for empty talk is over. Now arrives the hour of action. (16)

In addition, the glorification of action and the criticism of communication ("all talk") is levied not only at the general political structure (unnamed politicians) but also at specific politicians that, in Trump's view, embody the general political structure:

[To Ted Cruz:] You are all talk and no action. (10)

[To Hillary Clinton:] Typical politician. All talk, no action. Sounds good, doesn't work. Never going to happen. (13) 
[...] she [Hillary Clinton] talks about health care. Why didn't you do something about it? She talks about taxes. Why didn't she do something about it? She doesn't do anything about anything other than talk. With her, it's all talk and no action. (14)

\section{The Exactitude of Error Device: Xenophobic, Ethnonationalist Hyperbole}

The final device - "exactitude of error" - can be summarised as xenophobic, ethnonationalist hyperbole. As Adorno writes,

The figures mentioned in [Thomas's] diatribe are, of course, utterly fantastic. There is [not] the slightest corroboration of the astronomical figure of the "cost of crime" in America. To operate with fantastic figures is an established Nazi habit. The apparent scientific exactitude of any set of figures silences resistance against the lies hidden behind the figures. This technique which might be called the "exactitude of error" device is common to all fascists. Phelps, for instance, has similar fantastic figures about the influx of refugees into this country. The greatness of the figure, incidentally, acts as a psychological stimulant, suggesting a general feeling of grandeur which is easily transferred to the speaker (Adorno 2000, 93).

The exactitude of error device links xenophobia (fear of outsiders) and ethnocentrism (in the case of the United States, white supremacy and nationalism) through empirical (and largely false) racist referents. As a key theme of Trump's authoritarian populism is its usage of ethnocentrism, nationalism, and "law-and-order politics" to enact politically authoritarian capitalism (Fuchs 2018, 58), it is worth noting that the exactitude of error device is used precisely in a racist context. As Gounari $(2018,210)$ writes, US authoritarian populism does "politics through fear and terror while demonizing the different 'Other' and inciting racism", where "the image of the ostensible enemy is inflated out of all proportion to reality".

One of the most characteristic examples of Trump's usage of the exactitude of error device (i.e., xenophobic, ethnonationalist hyperbole) is the oft-quoted lines from his presidential announcement speech: "When Mexico sends its people, they're not sending their best. [...] They're sending people that have lots of problems, and they're bringing those problems with [sic] us. They're bringing drugs. They're bringing crime. They're rapists" (01). In what amounts to "xenophobic rhetorical excesses" (Abromeit $2018,15)$, the racist caricature of Mexican people is worth noting. However, it is also worth examining the wider context in which this line arises. In what precedes the "costs of crime" and "influx of refugees", Trump constructs a nostalgic narrative that frames what he believes to be the United States' decline. As Trump begins this narrative, he says, "Our country is in serious trouble. We don't have victories anymore. We used to have victories, but we don't have them. When was the last time anybody saw us beating [China, Japan, or Mexico]? [...] The U.S. has become a dumping ground for everybody else's problems" (01). It is also worth noting the themes of success ("victories") and violence ("beating") that are part and parcel of Trump's nostalgic narratives. Still, it is by employing hyperbole within these quotes ("dumping ground", "serious trouble", etc.) that Trump's usage of the exactitude of error device becomes clear. The exactitude of error device is also immediately utilised by Trump as he puts forward several statistics that demonstrate the presumably terrible circumstances of the United States: 
We spent $\$ 2$ trillion in Iraq, $\$ 2$ trillion. We lost thousands of lives, thousands in Iraq. [...] All over the place [we have] thousands and thousands of wounded soldiers. [...] Last week, I read 2,300 Humvees - these are big vehicles - were left behind for the enemy. 2,000? You would say maybe two, maybe four? 2,300 sophisticated vehicles, they ran, and the enemy took them. [...] And our real unemployment is anywhere from 18 to 20 percent. Don't believe the 5.6. Don't believe it. That's right. A lot of people up there can't get jobs. They can't get jobs, because there are no jobs, because China has our jobs and Mexico has our jobs. They all have jobs. But the real number, the real number is anywhere from 18 to 19 and maybe even 21 percent, and nobody talks about it, because it's a statistic that's full of nonsense. [...] Yesterday, it came out that [healthcare] costs are going for people up 29, 39, 49, and even 55 percent, and deductibles are through the roof. You have to be hit by a tractor, literally, a tractor, to use it, because the deductibles are so high, it's virtually useless. It's virtually useless. It is a disaster. And remember the $\$ 5$ billion website? $\$ 5$ billion we spent on a website, and to this day it doesn't work. A $\$ 5$ billion website. (01)

Trump mentions other numbers throughout the presidential announcement speech, but the rapid-fire nature of Trump's usage of statistics and numbers, many of which are often repeated ("thousands of lives, thousands", "\$5 billion website? \$5 billion", etc.) also demonstrate the usage of the exactitude of error device.

Trump's repeated reassertion of "law and order" forms another nostalgic discourse that is hardly 'new', serving as an important dog whistle for ethnonationalist, white supremacist rhetoric. As previously mentioned, this phrase has an extensive historical precedent within authoritarian populism in justifying white supremacism. Additionally, unlike other terms like "MAGA" or the various referents to the US political structure by Trump ("lobbyists", "special interests", etc.), "law and order" is positioned within an explicitly racial context. For instance, in the first presidential debate, Trump remarked that:

First of all, Secretary Clinton doesn't want to use a couple of words. And that's law and order. And we need law and order. If we don't have it, we're not going to have a country. [...] when I look at what's going on throughout various parts of our country - I can just keep naming them all day long - we need law and order in our country. [...] We have a situation where we have our inner cities, African Americans, Hispanics, are living in hell, because it's so dangerous. You walk down the street, you get shot. In Chicago, they've had thousands of shootings, thousands, since January 1st. Thousands of shootings. And I say, where is this? Is this a war-torn country? What are we doing? And we have to stop the violence, we have to bring back law and order, in a place like Chicago, where thousands of people have been killed. (13)

Additionally, Trump remarked in the third presidential debate that:

Our policemen and women are disrespected. We need law and order, but we need justice, too. Our inner cities are a disaster. You get shot walking to the store. They have no education. They have no jobs. I will do more for African Americans and Latinos than she can ever do in ten lifetimes. (15)

These two excerpts offer three themes at the intersection of racial discourse and politics. First, hyperbole (especially around and what constitutes criminality, but also 
immigrants and marginalized groups in general) is a common theme among right-wing populism; as previously noted, a primary tendency of fascism is to inflate and mobilise social anxieties by repeatedly over-exaggerating or altogether mischaracterising social problems (see Hall et al. 2013). This repeated mischaracterisation - or, as Adorno refers to it, this "exactitude of error" device - is common among authoritarian populists, overinflating both the "costs of crime" and "the influx of refugees" (Adorno 2000, 93). It should also be noted that this hyperbole within Trump's discourse extends well beyond the realm of crime, encapsulating education ("They have no education") and the economy ("They have no jobs"), as well as more general attitudes toward social life ("living in hell", "You walk down the street, you get shot", etc.).

Second, the phrase and surrounding discursive context of "law and order" explicitly draw on racial identities in putting forth authoritarian policies. Trump often talks about "Latinos, Hispanics, and African-American people" and how "law and order" will solve their problems: "African-American communities are being decimated by crime", "the people that are most affected by [crime] are African-American and Hispanic people", "making our inner cities better for the African-American citizens that are so great and for the Latinos, Hispanics", and so on. As previously noted, "law and order" has a significant racial dimension that operates behind a façade of racial colour-blindness; this colour-blindness façade is evident in the numerous attempts at racial parity ("we have to take care of people on all sides").

The third and final theme evident in the previous excerpts is police veneration: "Our policemen and women are disrespected", and "We have to bring back respect to law enforcement". While also present as a more implicit undercurrent in authoritarian populism, police veneration is a staple of fascist rhetoric. As implied by the term "authoritarianism", fascists seek to provide a groundwork for which a police state may be built through respect for authority, where this police system may effectively and brutally suppress all opposition, including those that do not fit within its parameters of racial and national identity.

\section{Conclusion}

Using Adorno's understudied textual analysis of the radio addresses of Martin Luther Thomas and Trump's 2016 US presidential campaign, this study extracted three rhetorical devices that Adorno uses to characterise Thomas and his authoritarian populism and transposed them to Trump. The first device was the lone wolf device amounting to anti-statism or pseudo-conservatism, most clearly exemplified through Trump's claim that he "turn[s] down so much [...] from special interests and donors", reflecting his criticism of "special interests" and his appraisal of business, especially his own ability to finance his presidential campaign. The second was the movement device, which amounts to glorification of action, most clearly exemplified through Trump's repeated claim that politicians are "all talk and no action". The third was the exactitude of error device, which amounts to xenophobic, ethnonationalist hyperbole, most commonly exemplified through his claim that "When Mexico sends its people, they're not sending their best. [...] They're sending people that have lots of problems, and they're bringing those problems with us. They're bringing drugs. They're bringing crime. They're rapists". Table 2 below provides a list and summary of the devices used in the analysis, with columns delineated as follows: device used by Adorno to elucidate authoritarian populism (Device), the study's definition of the device (Definition), Adorno's definition of the device derived from his Psychological Technique of Martin Luther Thomas's Radio Addresses (Adorno's Definition), and examples of Trump's 
rhetoric during the 2016 presidential campaign that can be characterised as using this device (Examples through Trump's Discourse).

\begin{tabular}{|c|c|c|c|}
\hline Device & Definition & Adorno's Definition & $\begin{array}{l}\text { Example through } \\
\text { Trump's Discourse }\end{array}$ \\
\hline Lone wolf & Anti-statism & $\begin{array}{l}\text { "The lone wolf device is taken } \\
\text { from the arsenal of Hitler, who } \\
\text { always used to boast [...] about } \\
\text { the fact that others controlled } \\
\text { the press, the radio- } \\
\text { everything; and that he had } \\
\text { nothing." }\end{array}$ & $\begin{array}{l}\text { "I turn down so much } \\
\text { [...] from special } \\
\text { interests and donors. } \\
{[. . .] \text { I am not accepting }} \\
\text { any money from } \\
\text { anybody. Nobody has } \\
\text { control of me other than } \\
\text { the people of this } \\
\text { country." }\end{array}$ \\
\hline Movement & $\begin{array}{l}\text { Glorification of } \\
\text { Action }\end{array}$ & $\begin{array}{l}\text { "The movement is conceived of } \\
\text { as an end in itself, like the Nazis } \\
\text { who always made a fetish of the } \\
\text { term Bewegung ["move" or "the } \\
\text { movement"] without pointing out } \\
\text { exactly where the Bewegung } \\
\text { was going." }\end{array}$ & $\begin{array}{l}\text { "I don't believe these } \\
\text { politicians. All talk, no } \\
\text { action." } \\
\text { "Typical politician. All } \\
\text { talk, no action. Sounds } \\
\text { good, doesn't work. } \\
\text { Never going to happen." }\end{array}$ \\
\hline $\begin{array}{l}\text { Exactitude } \\
\text { of error }\end{array}$ & $\begin{array}{l}\text { Xenophobic, } \\
\text { ethnonationalist } \\
\text { Hyperbole }\end{array}$ & $\begin{array}{l}\text { "To operate with fantastic } \\
\text { figures is an established Nazi } \\
\text { habit. The apparent scientific } \\
\text { exactitude of any set of figures } \\
\text { silences resistance against the } \\
\text { lies hidden behind the figures. } \\
\text { [...] The greatness of the figure, } \\
\text { incidentally, acts as a } \\
\text { psychological stimulant, } \\
\text { suggesting a general feeling of } \\
\text { grandeur which is easily } \\
\text { transferred to the speaker." }\end{array}$ & $\begin{array}{l}\text { "When Mexico sends its } \\
\text { people, they're not } \\
\text { sending their best. [...] } \\
\text { They're sending people } \\
\text { that have lots of } \\
\text { problems, and they're } \\
\text { bringing those problems } \\
\text { with us. They're } \\
\text { bringing drugs. They're } \\
\text { bringing crime. They're } \\
\text { rapists." } \\
\text { "Our inner cities are a } \\
\text { disaster. You get shot } \\
\text { walking to the store. } \\
\text { They have no } \\
\text { education. They have } \\
\text { no jobs." }\end{array}$ \\
\hline
\end{tabular}

Table 2: List and summary of devices

This study has excluded the religious component from Adorno's (2000) original analysis of right-wing demagoguery and authoritarian populism due to the remarkably secular discourse of Trump's presidential campaign. The value of the religious devices conceptualised in Psychological Technique have proved immensely useful in research on the Religious Right, such as Paul Apostolidis' analysis of the "New Right", especially James Dobson's multi-million dollar Christian organisation "Focus on the Family" (Apostolidis 2000, 59-62, 71-84). However, what makes Trump dissimilar from previous demagogues of the "New Right" is his infrequent employment of religious terminology. Indeed, during our analysis of Trump's 2016 US presidential campaign, we found that religious terms - such as "God", "Creator", "Bible", "Christ", "Jesus", "sin" 
and "soul" - were only mentioned a total of nine times. Out of these nine occurrences, five of them occurred in his prepared inaugural address. Thus, imminent research could and should untangle the religious and secular arguments of right-wing demagoguery and authoritarian populism. As mobilising fear, especially in regard to immigrants and people of colour, seem to be a recurrent feature of right-wing demagoguery, future studies may also benefit from a historical-comparative analysis of authoritarian populism.

Finally, it is clear that the rhetorical devices that Adorno catalogued remain relevant today. Critical theory may do well to classify to what degree authoritarian populism utilises these propaganda tricks and to what degree of overlap authoritarian populists use these devices. For instance, do other authoritarian populists utilise the lone wolf device, and to what degree is it successful? Do Marine Le Pen and Jair Bolsonaro utilise the exactitude of error device, and, if so, to what degree does this device factor into their rise in popularity? Whatever the answers may be, this study has found that Trump primarily utilised the lone wolf device (anti-statism), the movement device (glorification of action), and the exactitude of error device (xenophobic, ethnonationalist hyperbole) for his ultimately successful 2016 US presidential campaign.

\section{References}

Abromeit, John. 2018. Frankfurt School Critical Theory and the Persistence of Authoritarian Populism in the United States. In Critical Theory and Authoritarian Populism, edited by Jeremiah Morelock, 3-27. London: University of Westminster Press.

Adorno, Theodor W. 2000. The Psychological Technique of Martin Luther Thomas' Radio Addresses. Stanford, CA: Stanford University Press.

Adorno, Theodor W. 1994. The Stars Down to Earth: and Other Essays on the Irrational in Culture. New York: Routledge.

Adorno, Theodor W., Hans Albert, Ralf Dahrendorf, Jürgen Habermas, Harald Pilot, and Karl R. Popper. 1976. The Positivist Dispute in German Sociology. Translated by Glyn Adey and David Frisby. New York: Harper \& Row.

Adorno, Theodor W., Else Frenkel-Brunswik, Daniel J. Levinson, and R. Nevitt Sanford. 1950. The Authoritarian Personality. Oxford: Harpers.

Alexander, Michelle. 2011. The New Jim Crow: Mass Incarceration in the Age of Colorblindness. New York: The New Press.

Apostolidis, Paul. 2000. Stations of the Cross: Adorno and Christian Right Radio. Durham, NC: Duke University Press.

Ballestín, Lucas. 2017. Reading Adorno on Fascism in the Age of Trump: A New School Roundtable. Public Seminar. Accessed October 9, 2017. http://www.publicseminar.org/2017/10/reading-adorno-on-fascism-in-the-age-of-trump

Bernstein, Jay M. 2017. Adorno's Uncanny Analysis of Trump's Authoritarian Personality. Public Seminar. Accessed October 9, 2017. http://www.publicseminar.org/2017/10/adornos-uncanny-analysis-of-trumps-authoritarianpersonality

Brittain, Christopher Craig. 2018. Racketeering in religion: Adorno and evangelical support for Donald Trump. Critical Research on Religion 6 (3): 269-288. doi: $10.1177 / 2050303218800382$.

Center for Responsive Politics (CRP). 2018. Summary Data for Donald Trump, 2016 Cycle. Center for Responsive Politics. Accessed July 29, 2018. https://www.opensecrets.org/pres16/candidate?id=N00023864

Dubiel, Helmut. 1985. Theory and politics: Studies in the development of critical theory. Translated by Benjamin Gregg. Cambridge: MIT Press.

Eco, Umberto. 1995. Ur-Fascism. The New York Review of Books. Accessed January 23, 2018. http://www.nybooks.com/articles/1995/06/22/ur-fascism/ 
Fereday, Jennifer, and Eimear Muir-Cochrane. 2006. Demonstrating Rigor Using Thematic Analysis: A Hybrid Approach of Inductive and Deductive Coding and Theme Development. International Journal of Qualitative Methods 5 (1): 80-92. https://doi.org/10.1177/160940690600500107

Flamm, Michael. 2007. Law and Order: Street Crime, Civil Unrest, and the Crisis of Liberalism in the 1960s. New York: Columbia University Press.

Frank, David A. 2011. Obama's Rhetorical Signature: Cosmopolitan Civil Religion in the Presidential Inaugural Address, January 20, 2009. Rhetoric and Public Affairs 14 (4): 605630. doi: 10.1353/rap.2011.0044.

Fuchs, Christian. 2018. Digital Demagogue: Authoritarian Capitalism in the Age of Trump and Twitter. London: Pluto Press.

Galloway, George. 2016. Clinton \& Trump Both Representatives of Oligarchy' - Jill Stein, Green Party Presidential Candidate. RT. Accessed August 7, 2018. https://www.rt.com/op-ed/333839-clinton-trump-stein-oligarchy/

Gandesha, Samir. 2018. Understanding Right and Left Populism. In Critical Theory and Authoritarian Populism, edited by Jeremiah Morelock, 49-70. London: University of Westminster Press.

Gordon, Ann, and Jerry L. Miller. 2004. Values and Persuasion During the First Bush-Gore Presidential Debate. Political Communication 21 (1): 71-92. doi: 10.1080/10584600490273272.

Gordon, Peter E. 2016. The Authoritarian Personality Revisited: Reading Adorno in the Age of Trump. boundary 2. Accessed August 20, 2017.

http://www.boundary2.org/2016/06/peter-gordon-the-authoritarian-personality-revisitedreading-adorno-in-the-age-of-trump/

Gounari, Panayota. 2018. Authoritarianism, Discourse and Social Media: Trump as the 'American Agitator'. In Critical Theory and Authoritarian Populism, edited by Jeremiah Morelock, 207-227. London: University of Westminster Press.

Gramlich, John. 2019. 5 facts about crime in the U.S. Pew Research Center. Accessed July 4, 2019. https://www.pewresearch.org/fact-tank/2019/01/03/5-facts-about-crime-in-the-u-s/

Hall, Stuart, Chas Critcher, Tony Jefferson, John Clarke, and Brian Roberts. 2013. Policing the Crisis: Mugging, the State, and Law and Order. London: Macmillan.

Horkheimer, Max, and Theodor W. Adorno. 1972. Dialectic of Enlightenment: Philosophical Fragments. Translated by John Cumming. New York: Herder and Herder.

James, Nathan. 2018. Recent Violent Crime Trends in the United States. Congressional Research Service. Accessed July 1, 2019. https://fas.org/sgp/crs/misc/R45236.pdf

Jay, Martin. 1973. The Dialectical Imagination: A History of the Frankfurt School and the Institute of Social Research 1923-1950. London: Heinemann.

Johnson, Paul Elliott. 2017. The Art of Masculine Victimhood: Donald Trump's Demagoguery. Women's Studies in Communication 40 (3): 229-250. doi: 10.1080/07491409.2017.1346533.

Kellner, Douglas. 2018a. Donald Trump as Authoritarian Populist: A Frommian Analysis. In Critical Theory and Authoritarian Populism, edited by Jeremiah Morelock, 71-81. London: University of Westminster Press.

Kellner, Douglas. 2018b. Preface to Critical Theory and Authoritarian Populism. In Critical Theory and Authoritarian Populism, edited by Jeremiah Morelock, xi-xii. London: University of Westminster Press.

Maly, Michael, Heather Dalmage, and Nancy Michaels. 2012. The End of an Idyllic World: Nostalgia Narratives, Race, and the Construction of White Powerlessness. Critical Sociology 39 (5): 757-779. https://doi.org/10.1177/0896920512448941

Marietta, Morgan. 2009. The Absolutist Advantage: Sacred Rhetoric in Contemporary Presidential Debate. Political Communications 26 (4): 388-411. https://doi.org/10.1080/10584600903296986 
Morelock, Jeremiah, and Felipe Ziotti Narita. 2018. Public Sphere and World-System: Theorizing Populism at the Margins. In Critical Theory and Authoritarian Populism, edited by Jeremiah Morelock, 135-153. London: University of Westminster Press.

Müller, Jan-Werner. 2016. What Is Populism? Philadelphia, PA: University of Pennsylvania Press.

Pelinka, Anton. 2013. Right-Wing Populism: Concept and Typology. In Right-Wing Populism in Europe: Politics and Discourse, edited by Ruth Wodak, Majid KhosraviNik and Brigitte Mral, 3-22. London: Bloomsbury Academic.

Pew Research Center. 2010. Public Knows Basic Facts about Politics, Economics, But Struggles with Specifics. Pew Research Center. Accessed August 18, 2018. http://www.pewresearch.org/2010/11/18/public-knows-basic-facts-about-politicseconomics-but-struggles-with-specifics/

Reber, Bryan H., and William L. Benoit. 2001. Presidential Debate Stories Accentuate the Negative. Newspaper Research Journal 22 (3): 30-43. https://doi.org/10.1177\%2F073953290102200303

Richards, Tom, and Lyn Richards. 2003. The Way Ahead in Qualitative Computing. Journal of Applied Statistical Methods 2 (1):16-26. doi: 10.22237/jmasm/1051747440

Ross, Alex. 2016. The Frankfurt School Knew Trump was Coming. The New Yorker. Accessed August 29, 2017. http://www.newyorker.com/culture/cultural-comment/thefrankfurt-school-knew-trump-was-coming

Rydgren, Jens. 2003. Meso-level Reasons for Racism and Xenophobia: Some Converging and Diverging Effects of Radical Right Populism in France and Sweden. European Journal of Social Theory 6 (1): 45-68. https://doi.org/10.1177/1368431003006001560

Saldaña, Johnny. 2016. The Coding Manual for Qualitative Researchers [3rd edition]. London: Sage.

Sanders, Bernie. 2010. No to Oligarchy. The Nation. Accessed August 7, 2018. https://www.thenation.com/article/no-oligarchy/

Smith, David Norman, and Eric Hanley. 2018. The Anger Games: Who Voted for Donald Trump in the 2016 Election, and Why? Critical Sociology 44 (2):195-212. https://doi.org/10.1177/0896920517740615

Time. 2015. "Here's Donald Trump's Presidential Announcement Speech." Time. Accessed July 24, 2019. https://time.com/3923128/donald-trump-announcement-speech/

Trump, Donald J. 2017. Remarks of Presidents Donald J. Trump - As Prepared for Delivery: Inaugural Address. White House. Accessed April 15, 2019. https://www.whitehouse.gov/briefings-statements/the-inaugural-address/

Walker, Hunter. 2014. A Shocking Number of Americans Don't Know Basic Facts About the US Government. Business Insider. Accessed August 18, 2018. https://www.businessinsider.com/poll-many-americans-dont-know-basic-facts-aboutgovernment-2014-9

\section{About the Authors}

\section{Myra B. Haverda}

Myra B. Haverda received an M.S. in Sociology at the University of Texas at San Antonio and is currently a doctoral student at the University of Oregon. Their research focuses on critical theory, masculinity studies, and social movements. Their master's thesis, "Hybridizing Masculinity: Gender Identity Negotiation Among Men's Rights Activists," is a qualitative analysis that draws from fifteen interviews with men's rights activists, finding that men's rights activists engage in three forms of masculinity hybridization: fortifying boundaries, strategic borrowing, and discursive distancing.

Jeffrey A. Halley

Jeffrey A. Halley is Professor of Sociology at the University of Texas at San Antonio, where he directs the Laboratory for the Sociology of the Arts, Culture, and Communications (SACC). His 
research and teaching focuses on theory, art, culture, and media. Recent articles concern the problem of the rationalization of culture in the Dada art movement, Mexican American Conjunto music, and standardization and pleasure in the wine world. In 2010 and 2011 he was Guest Editor of two volumes of Sociologie De l'Art, Théorie/Epistémologie/Littérature, and "Rationalisation et Résistance/Postmodernisme". In 2017 he edited, with Daglind Sonolet, Bourdieu in Question: New Directions in French Sociology of Art (Leiden/Boston: Brill Publishers). He has been a Fulbright Fellow, and guest professor at the universities of Ljubljana, Metz, and the École des Hautes Études en Sciences Sociales, Paris, France. He was elected President, Research Committee on the Sociology of the Arts, the International Sociological Association, and is on the editorial board of Sociologie de l'art and Comparative Sociology. 